\title{
SIMULASI VISUAL GEDUNG SERBAGUNA (GSG) UNIVERSITAS LAMPUNG MENGGUNAKAN GOOGLE EARTH DENGAN APLIKASI 3D SKETCHUP 2019
}

\author{
Kelik Hendro Basuki \\ Program Studi Arsitektur, Jurusan Teknik Sipil, Fakultas Teknik, \\ Universitas Lampung, J1. Soemantri Brojonegoro No.1, Bandar Lampung \\ Email: jaya_setika@yahoo.com
}

\begin{abstract}
Abstrak
Kemampuan dalam menyajikan bentuk visual yang didukung oleh lingkungan sekitar menjadi sebuah penambahan kejelasan informasi tentang letak dari objek yang akan dituju oleh setiap individu yang membutuhkannya. Melihat foto, nama jalan yang tercantum di alamat tertentu menjadi hal yang lazim yang selama ini akan menjadi langkah awal bagi setiap individu dalam mencari sebuah alamat yang dituju. Lokasi kordinat menjadi semakin popular saat ini terutama dalam berbagi lokasi dari satu individu ke individu lainnya. Google Earth, menjadi bagian global yang dapat melengkapi informasi yang di dapatkan. Lokasi strategis, gedung-gedung penting, restaurant, nama jalan, fasilitas umum terdekat dapat dengan mudah terlihat saat kita mencari menggunakan Global Positioning System (GPS). Semua informasi tersebut akan hadir pada sebuah tampilan Google Map yang berbasis pada Google Earth yang dapat terlihat pada sebuah smartphone atau komputer. Di beberapa negara google earth sudah terekam dalam bentuk 3d bangunannya. Namun belum di Indonesia. Oleh sebab itu peneliti mencoba membuat sebuah simulasi yang dalam hal ini adalah Gedung Serba Guna (GSG) Universitas Lampung dalam bentuk 3D Menggunakan aplikasi SketchUp yang dapat diakses menggunakan aplikasi google earth yang berbasis web. Dapat di lihat berbagai arah, tidak hanya menampilkan bagian muka, dan dapat menyerupai kondisi fisik aslinya merupakan beberapa point penting yang menjadi hasil dari penelitian ini.
\end{abstract}

Kata kunci: 3d Visual, Google Earth, SketchUp

\section{PENDAHULUAN}

a. Latar Belakang

Kebutuhan akan informasi yang jelas tentang letak dan sosok ataupun wujud dari sebuah bangunan yang menjadi tujuan dalam sebuah destinasi menjadi sangat penting sekali. Hal ini akan memberikan pilihan kepada setiap individu yang akan menuju ke lokasi yang mereka inginkan dengan dan bagaimana mereka mencapainya.

Orientasi bangunan terhadap lingkungan sekitar juga akan terlihat lebih jelas saat informasi yang disampaikan mengikutsertakan bagaimana kondisi di sekitar objek yang akan dituju. Yang dalam hal ini adalah Gedung Serba Guna (GSG) Unila. Informasi mengenai akses dan pencapaian, ruang parkir, kondisi RTH, objek terkait disekitar bangunan, bahkan pada jumlah dan bagaimana pintu masuk ke dalam bangunan menjadi informasi yang penting bagi bangunan yang menjadi pusat kegiatan saat kegiatan besar dilaksanakan. Salah satunya kegiatan rutin yaitu acara wisuda yang setiap dua bulan sekali dilaksanakan. Pengunjung bukan hanya mahasiswa Unila sendiri namun juga orang tua, saudara yang mungkin belum pernah berkunjung ke GSG Unila. Terlebih saat gedung ini digunakan oleh Universitas lain dalam kegiatan yang sama.
Rona bumi yang dapat tampil pada aplikasi Google Earth menjadi sangat popular saat ini seiring dengan populernya aplikasi motion tracking dengan Global Positioning System (GPS) yang tersemat pada smartphone. Aplikasi ini menjadi pilihan yang umum saat kebutuhan akan sebuah perjalanan ataupun pencarian alamat menjadi sebuah tujuan. Oleh sebab itu penelitian ini mencoba menggunakan Google Earth sebagai base dari posisi GSG Unila.

\section{b. Rumusan Masalah}

Dari latar belakang diatas penulis ingin membuat sebuah penilitian dengan merumuskan sebuah pemikiran "Bagaimana mensimulasikan sebuah objek $3 \mathrm{~d}$ arsitektur yang dalam hal ini adalah GSG Unila, yang mengikutsertakan informasi tentang gedung GSG itu sendiri berikut juga informasi tentang area sekitar, berbasis Google Earth".

\section{ISI PENELITIAN}

\section{a. Metode Penelitian}

Metode yang digunakan dalam hal ini adalah Simulasi. Simulasi yang dilakukan menggunakan perangakat lunak yang dapat di gunakan secara offline yaitu SketchUp dan aplikasi yang dapat di akses secara online yaitu Google Earth. 
SketchUp digunakan untuk membuat bentukan 3d Model atau 3d objek yang akan di tempatkan ke dalam kordinat yang berada di Google Earth.

\section{b. Alat dan Bahan}

Didalam pelaksanaan simulasi ini membutuhkan alat dan bahan yang memiliki spesifikasi khusus. Adapaun alat yang digunakan adalah 1 (satu) unit komputer pengolah data grafis dengan spesifikasi:

1) Processor Intel Core i7-5930K,

2) RAM: $32768 \mathrm{MB}$,

3) Graphic Display: MSI NVIDIA GTX 980Ti,

4) Motherboard: MSI Extreme Gaming Intel X99 LGA 2011-v3 DDR4,

5) Power Supply: XFX850 Watt,

6) Led Display : Ultrawide IPS LG 25UM58,

7) Keyboard\& Mouse.

Dan untuk bahan yang di gunakan adalah objek tiga dimensi dari Gedung Serba Guna (GSG) Universitas Lampung yang dibuat menggunakan SketchUp.

\section{HASIL DAN PEMBAHASAN}

a. Hasil

Dalam hal ini akan di awali dengan menggambarkan bentuk GSG Universitas Lampung yang didasarkan atas data ukur yang kemudian diolah dengan perangkat lunak Autodesk Autocad, yang hasilnya adalah layout denah GSG. Dilanjutkan dengan mengimport data tersebut ke dalam SketchUp.

Langkah pertama kali yang di lakukan adalah dengan membuka SketchUp dengan tampilan interface awal berikut ini.

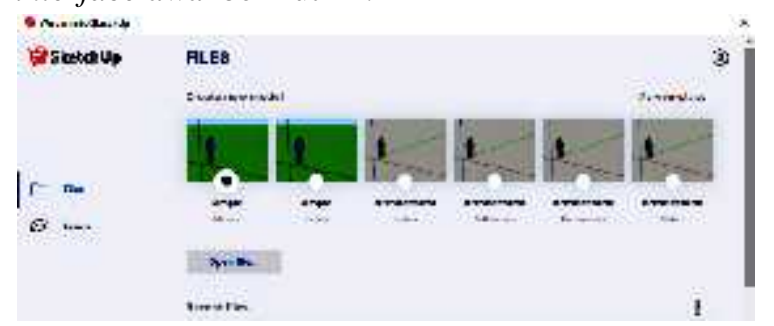

Gambar 1.Pemilihan Template

Gambar di atas adalah menu awal yang akan muncul saat awal pembukaan SketchUp. Ini merupakan menu dalam pemilihan template yang di bedakan atas Style dan dimensi gambar. Terdapat beberapa template yang disediakan yaitu dalam satuan meters, inches, centimeters, milimeters dan masih banyak lainnya dengan cara menggeser ke bawah atau dengan klik 2 kali pada "more template". Begitu juga dengan style dapat langsung dipilih menyesuaikan ukurannya.

Langkah selanjutnya adalah masuk kedalam SketchUp dengan tampilan berikut ini

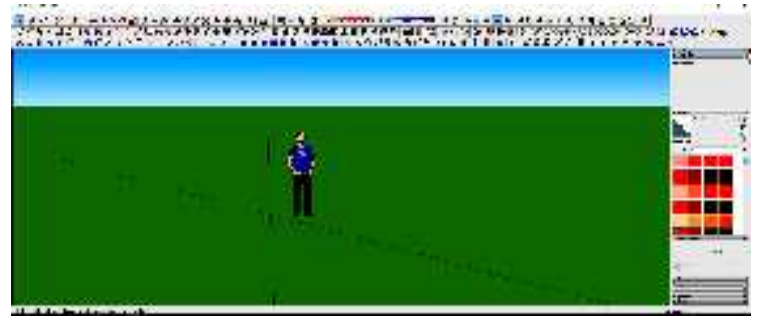

Gambar 2.Interface Awal

Setelah masuk kedalam perangkat lunak SketchUp kemudian proses penggambaran di mulai dengan bagian bawah sebagai dasar yang yang menjadi tapak bangunan dari GSG ini. Dengan terlebih dahulu mengimport file berekstensi *.dwg yang merupakan ekstensi default dari perangkat lunak Autodesk Autocad. Dilanjutkan dengan penggambaran bentuk lainnya.

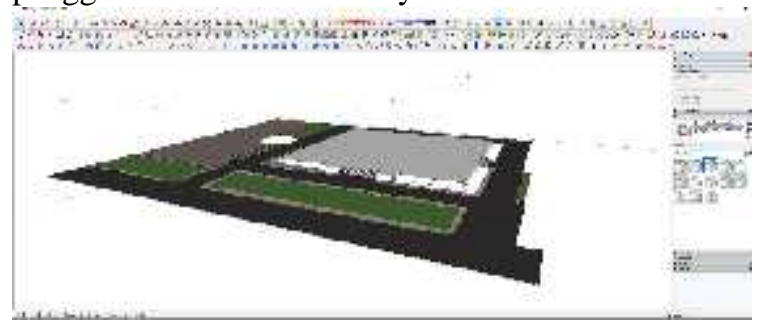

Gambar 3.Pembuatan bagian dasar GSG
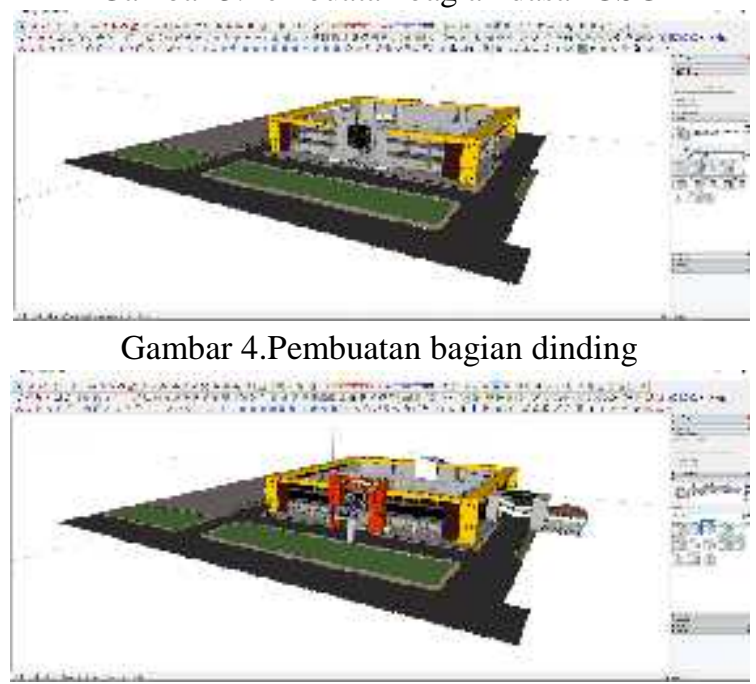

Gambar 5.Pembuatan bagian ornamentasi

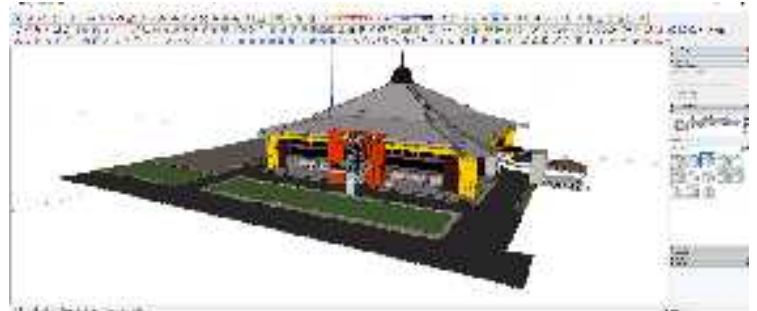

Gambar 6.Pembuatan bagian atap

Langkah selanjutnya adalah dengan mengimport peta google earth ke dalam SketchUp dengan terlebih dahulu menempatkan posisi bangunan GSG ini tepat di bagian tengah garis kordinat $\mathrm{x}, \mathrm{y}, \mathrm{z}=$ $0,0,0$. 


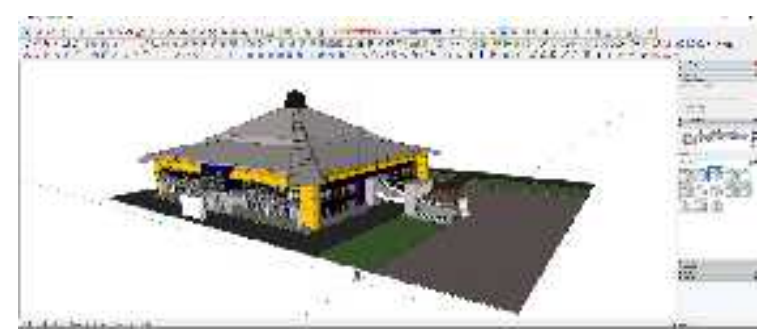

Gambar 7.Posisi kordinat sebelum digeser

Agar tidak ada satupun yang tertinggal saat menggeser bangunan mendekati titik pusat garis kordinat, maka semua bagian gedung digabungkan terlebih dahulu dengan "group". Caranya dengan seleksi semua dengan drag mouse melingkupi semua bagian gedung atau dengan menekan $C t r l+A$ pada keyboard.

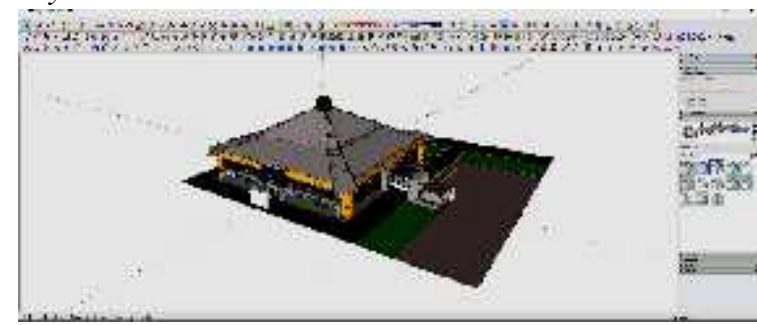

Gambar 8.Posisi kordinat setelah digeser

Setelah tepat berada di tengah maka selanjutnya meingimport google earth dengan menggunakan toolbars "add location". Atau dengan mengarahkan kursor ke "File - Geo location - Add location".
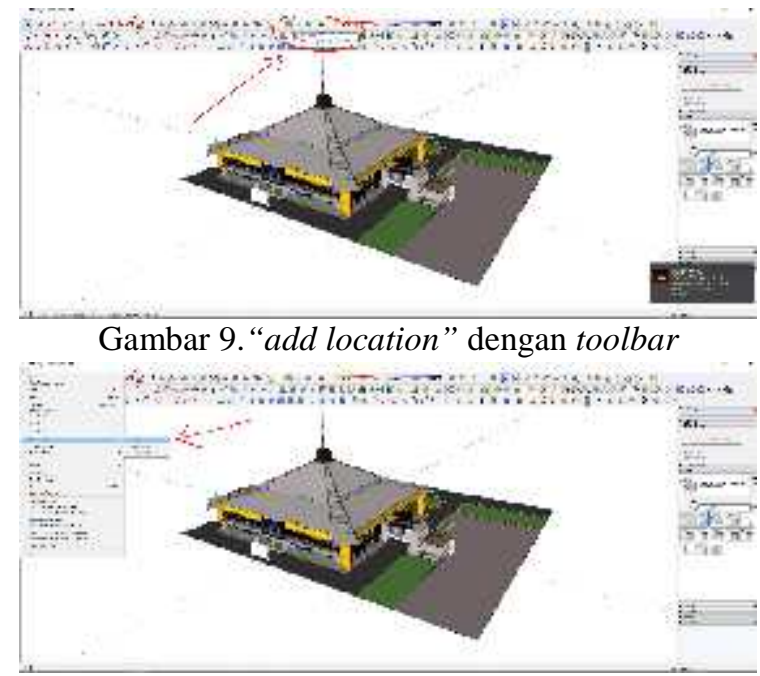

Gambar 10. “add location” dengan menu bar

Selanjutnya pilihlah lokasi yang merupakan kordinat lokasi GSG Unila. Setelah dikira pas luasan atau area yang dipilih kemudian klik import pada sisi bagian kanan menu.

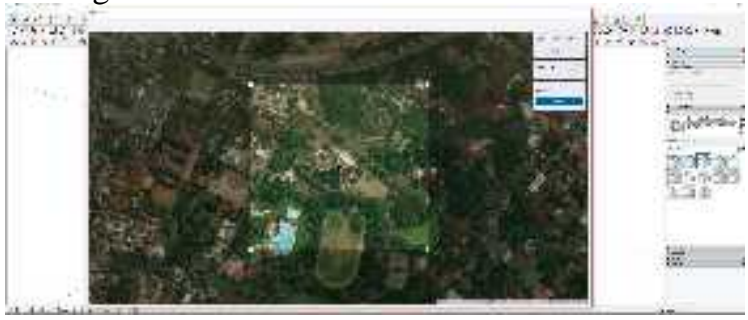

Gambar 11. Lokasi GSG Unila
Setelah diimport maka akan terlihat seperti gambar di bawah ini.

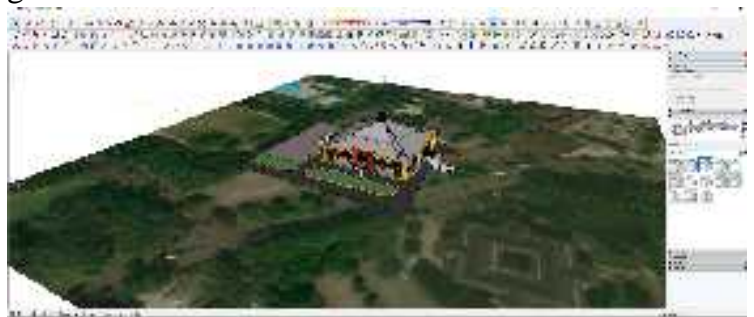

Gambar 12.Hasil "import location"

Kemudian dilanjutkan dengan penyesuaian orientasi bangunan terhadap lahan dengan cara merortasikan arah bangunan ke arah jalan utama sebagai bagian depan bangunan GSG ini dengan cara rotate toolbar atau arahkan kursor ke menu bar "Tools-Rotate"

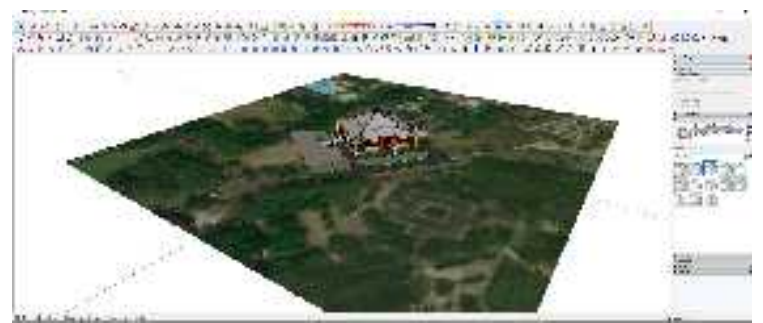

Gambar 13.Penyesuaian orientasi bangunan

Setelah sesuai maka simpan file, kemudian export file ke dalam file berekstensi $* . k m z$ dengan cara arahkan kursor ke File-Export-3d Model pada menu bar.Tulis nama file pastikan tipe filenya berekstensi *.kmz, kemudian klik export.

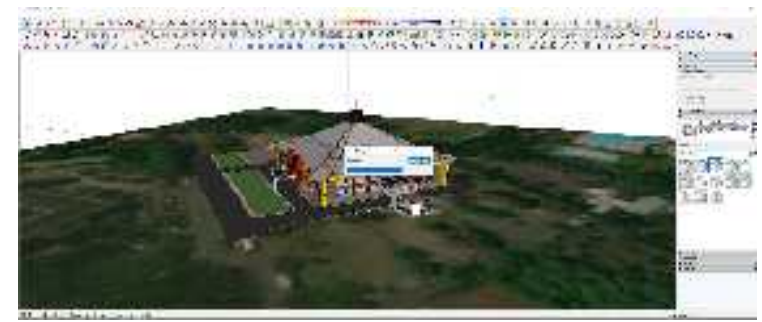

Gambar 14.Proses "export file”

\section{b. Pengujian}

Setelah proses export file berhasil maka selanjutnya dapat diuji dengan membuka applikasi berbasis online yaitu Google Earth.

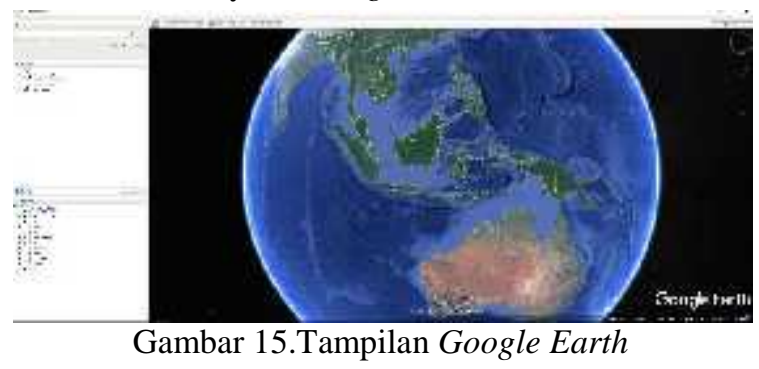

Selanjutnya adalah proses membuka file berekstensi *.kmz tersebut melalui aplikasi Google 
Earth ini dengan cara mengarahkan kursor ke FileOpen atau menekan Ctrl-O di keyboard.Kemudian pilih file yang dimaksud dan gambar bola bumi yang ada di tampilan akan berputar dan mengarah ke lokasi yang dimaksud. Proses tampilnya objek akan memakan waktu yang berbeda-beda bergantung pada kerumitan objek yang akan mempengaruhi besar file dankonektifitas jaringan yang digunakan saat pengujian berlangsung.

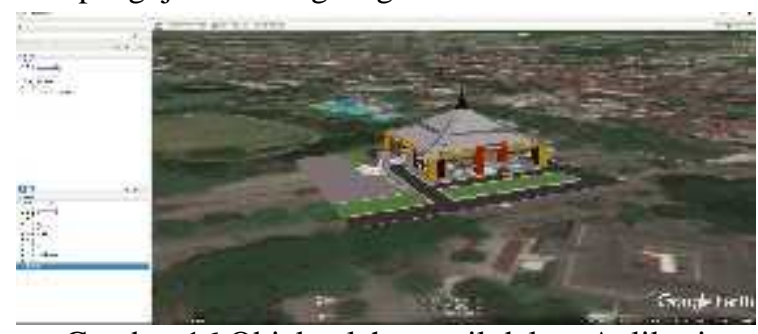

Gambar 16.Objek telah tampil dalam Aplikasi Google Earth

\section{KESIMPULAN}

Dari penelitian yang dilakukan terdapat beberapa kelebihan dan kekurangan. Adapun kelebihannya diantaranya yaitu; cara ini sangat efektif untuk dapat memberikan informasi mendetail terhadap wujud dari objek yang akan disampaikan, memberikan informasi yang lebih secara 3 dimensional dari berbagai sisi bila dibandingkan dengan google street view yang hanya memperlihatkan dari sisi yang menghadap ke arah jalan, dapat membantu berkontribusi terhadap wujud 3 dimensional google earth seperti yang dapat dilihat di beberapa negara yang memang sudah berbentuk 3 dimensional gedung-gedungnya, dan akses dapat dengan mudah hanya dengan menggunakan file yang telah di buat melalui proses diatas. Adapun kekurangan yang terjadi selama proses uji coba berlangsung diantaranya kompleksitas objek dan konektifitas jaringan sangat bergantung pada proses load file di dalam aplikasi google earth.

Penggunaan perangkat lunak sangat bergantung pada kemampuan dari perangkat keras yang terinstal di dalam sebuah CPU untuk melakukan penelitian ini. Sehingga keseimbangan antara berbeagai komponen sangat dibutuhkan. Penelitian ini perlu di lanjutkan dengan penelitian selanjutnya yang mengarah pada distribusi file yang dapat langsung terintegrasi informasinya dengan pemilik aplikasi Google Earth. Jadi dengan kata lain data file sudah dapat dilihat langsung seperti di negara-negara lain yang bangunannya sudah berbentuk 3 dimensional tanpa harus membuka file khusus dibuat seperti didalam penelitian ini.

\section{DAFTAR PUSTAKA}

Naisoko, Maria Wilfrida., Choir, Handriyas Abu., Ayu,Adheik Timor. (2014) Pembuatan Visualisasi Kampus ITN Malang Berbasis Web3d Menggunakan Google Earth, Usulan
Program Kreativitas Mahasiswa, Institut Teknologi Nasional, Malang.

Wijaya, Hendy \& Herru, 2007, Analisis Dan Perancangan Perangkat Ajar Berbasiskan Permainan Komputer 3d Online Tentang Pengetahuan Peta, Atlas Dan Globe Menggunakan Torque Game Engine, Hal 2627. Jakarta : Universitas Bina Nusantara. mril, 14-15. 